\title{
OPTIMIZATION OF DITERPENES BIOCONVERSION PROCESS BY THE FUNGUS CEPHALOSPORIUM APHIDICOLA
}

\author{
Jacqueline Aparecida Takahashi ${ }^{*}$; Henrique de Almeida Barroso²; Alaíde Braga de Oliveira² \\ ${ }^{1}$ Departamento de Química, ICEx, Universidade Federal de Minas Gerais, Belo Horizonte, MG, Brasil. ${ }^{2}$ Departamento de \\ Produtos Farmacêuticos, Faculdade de Farmácia, Universidade Federal de Minas Gerais, Belo Horizonte, MG, Brasil
}

Submitted: June 30, 1998; Returned to authors for corrections: September 15, 1998; Approved: June 26, 2000

\begin{abstract}
Parameters for a more efficient biotransformation of diterpene-like compounds by the fungus Cephalosporium aphidicola were established by carrying out microscale feedings at several conditions. Experiments were guided by thin layer chromatography and gas chromatography analysis. It was observed that the substrate should be added in ethanol at concentrations between 15 to $30 \mathrm{mg}$ per $100 \mathrm{ml}$ of medium. The extraction of the product showed to be more efficient when carried out from both mycelia and broth and using ethylacetate as the extracting solvent. The experiment should be stopped six days after feeding the substrate to the fungus for the best product yield.
\end{abstract}

Key words: Cephalosporium aphidicola, biotransformation, diterpene

\section{INTRODUCTION}

The problems associated with the use of racemic drugs, like thalidomide in the 1960s, led pharmaceutical and foodstuffs industries to look for new approaches to the synthesis of enantiomeric pure compounds. That fact, associated to the report of a number of well succeeded microbial transformations of substances with commercial value (2) has called attention of chemists for this kind of reactions. Microorganisms and enzymes are efficient chiral catalysts and their use as part of a strategy for enantiospecific syntheses have significantly increased nowadays (6).

Disadvantages related to the use of microbial transformations is mainly associated to low yield, need of specific laboratory equipments associated with the requirement of previous training on microbial techniques before starting a bioconversion experiment (3). Previous determination of conditions for the overall biotransformation process enable this kind of experiments to become more useful and faster, avoiding degradation and/or over metabolization of a specific product.

In this context, it was carried out a study on the incubation conditions for feeding the diterpenoid methyl trachylobanoate to the fungus Cephalosporium aphidicola. Several experiments were carried out to evaluate maximum amount of substrate to be added per flask, solvent for substrate addition, best incubation time for single product formation and methodology for product recovery. The results can be useful as a guide for feeding of similar compounds to the same fungus species.

\section{MATERIALS AND METHODS}

Gas Chromatography (GPC) : Experiments were carried out on a GC 3400 (Varian) FID equipment using flow rate of 1 $\mathrm{mLmin}^{-1}$, capillary column SE54 $(0.25 \times 30 \mathrm{~m})$ operating at $80^{\circ} \mathrm{C}$ $(3 \mathrm{~min}) ; 80-210^{\circ} \mathrm{C}\left(10^{\circ} \mathrm{min}^{-1}\right) ; 210-300^{\circ}\left(5^{\circ} \mathrm{min}^{-1}\right)$.

Thin Layer Chromatography (TLC): silica gel pre-coated plates were eluted with the solvent system: hexane:etilacetate (9.5.:0.5) and spots were observed after spraying with ceric sulphate $/ \mathrm{H}_{2} \mathrm{SO}_{4}$ followed by heating.

Preculture of $\boldsymbol{C}$. aphidicola. $C$. aphidicola (provided by Dr. James R. Hanson, University of Sussex - U.K.) maintained in potato dextrose agar (PDA) was inoculated into a conical flask containing sterilised culture medium $(1)$ and shaken at room temperature $\left(28^{\circ} \mathrm{C}\right)$ for 3 days. The broth was then transferred on to ten $250 \mathrm{ml}$ conical

\footnotetext{
* Corresponding author. Mailing address: Departamento de Química, ICEx, UFMG, Av. Antonio Carlos, 6627, CEP 31270-901, Belo Horizonte, MG, Brasil. Email: jacfab@dedalus.lcc.ufmg.br
} 
flasks containing $100 \mathrm{ml}$ of the same media each.

Feeding experiments. The substrate (methyl trachylobanoate) was added ( 5 to $50 \mathrm{mg} / 100 \mathrm{ml}$ ) after three days. Two control experiments named $\mathrm{C} 1$ (consisted of media plus fungus without addition of substrate) and $\mathrm{C} 2$ (consisted of media plus substrate only) were performed simultaneously. The bioconversion process was followed by TLC and GC for ten days. Two experiment flasks and one of each $\mathrm{C} 1$ and $\mathrm{C} 2$ flasks were filtered each 48 hours and the aqueous layers were submitted to analysis. Extraction was carried out with chloroform or ethyl acetate (1). Organic layers were evaporated down and the residues were analysed by TLC and GC. The best solvent for dissolving the substrate was determined carrying out experiments with dimethylsulphoxide (DMSO), dimethylformamide (DMF) and ethanol $(0.1 \mathrm{ml}$ per $\mathrm{mg}$ of substrate). Optimal substrate concentration to be added to $100 \mathrm{ml}$ of culture medium was evaluated by an experiment using a set of ten flasks with increasing amounts of substrate per flask.

\section{RESULTS AND DISCUSSION}

DMSO, DMF and ethanol were tested as solvents for methyl trachylobanoate addition in feeding experiments to the fungus C. aphidicola. DMSO was inadequate, as it promotes the formation of a self-derivative in the media. DMF remained in the organic layer at the end of the experiments. The use of DMSO and DMF is, therefore, discouraged but they may be the only options for the feeding of compounds not soluble in ethanol. This later proved to be the best addition solvent, showing to be completely evaporated after 24 hours of incubation. It also did not leave any residues in the media. In addition, no ethanol derivatives were detected in the control flasks. This solvent has proved to be the best choice also for use in bioconversion process with the fungus Glomerella cingulata (4).

In order to choose the best solvent for product recovery, extractions were carried out with chloroform and ethyl acetate. Chloroform extraction (CE) led to a difficult work up due to the formation of a persistent emulsion while ethyl acetate extraction (EAE) showed no work up problems. TLC comparison of residues from $\mathrm{CE}, \mathrm{EAE}$ and respective control experiments showed that chloroform promotes the extraction of a greater number of cellular components leading to a less productive chromatographic purification of the desired product. Exhaustive extraction of mycelia sometimes led to the detection, by TLC, of bioconversion products and therefore this step should be included in the process, in order to obtain better yields of microbial transformation products.

Adequate amount of substrate to be added per flask was evaluated by feeding a set of ten flasks with increasing concentrations of methyl trachylobanoate. After incubation time, each reaction flask was worked out and the extracts were analysed by TLC and GC (Table 1).
Table 1. Effect of substrate concentration in the feeding of methyl trachylobanoate (1) to Cephalosporium aphidicola for 8 days.

\begin{tabular}{cccc}
\hline $\begin{array}{c}\text { Flask } \\
\text { number }\end{array}$ & $\begin{array}{c}\text { Substrate added } \\
(\mathrm{mg} / 100 \mathrm{ml})\end{array}$ & $\begin{array}{c}\text { Number of } \\
\text { major spots }^{\mathrm{a}}\end{array}$ & $\begin{array}{c}\text { unaltered } \\
\text { substrate }(\%)\end{array}$ \\
\hline 1 & 5 & 0 & 0 \\
2 & 10 & 0 & 0 \\
3 & 15 & 1 & 0 \\
4 & 20 & 1 & 0 \\
5 & 25 & 2 & 0 \\
6 & 30 & 2 & 10 \\
7 & 35 & 1 & 50 \\
8 & 40 & 0 & 50 \\
9 & 45 & 0 & 60 \\
10 & 50 & 0 & 95 \\
\hline
\end{tabular}

${ }^{\mathrm{a}} \mathrm{TLC}=$ Thin Layer Chromatography

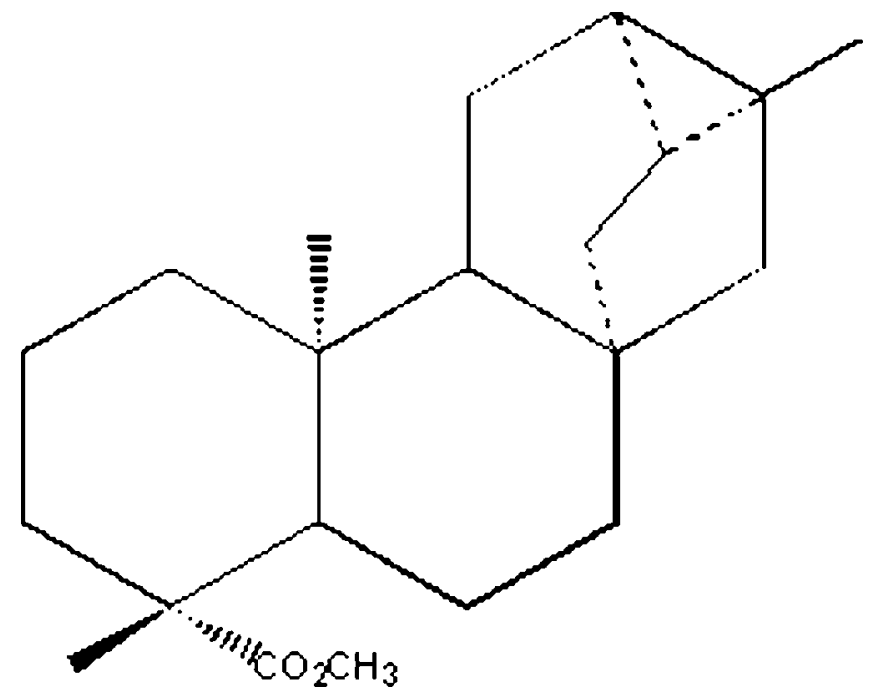

Figure 1. Chemical structure of methyl trachylobanoate used in the bioconversion experiments.

The results indicate that the maximal concentration of substrate to be added per $100 \mathrm{ml}$ of media is $30 \mathrm{mg}$, since concentrations higher than this significantly decrease the bioconversion efficiency. Addition of lower amounts of substrate $(5-10 \mathrm{mg} / 100 \mathrm{ml})$ led to difficulties for detection, by TLC, of the products in microscale experiments. However larger scale experiments using this range of concentration can be carried out. (5). Addition of 15 and $20 \mathrm{mg}$ of substrate per flask led to the detection (TLC) of only one major product, while with 25 and $30 \mathrm{mg} /$ flask, two major compounds were observed.

The incubation time is one of the most important parameters to be considered in order to have a high yield of a biotransformation product. To evaluate this parameter, the 
substrate ( $20 \mathrm{mg} / 100 \mathrm{ml}$ of medium) was fed to six conical flasks containing a grown culture of $C$. aphidicola. Controls $\mathrm{C} 1$ and $\mathrm{C} 2$ were carried out simultaneously. Extractions were carried out each 48 hours and samples were analysed by TLC and GC. No bioconversion of the substrate was observed in $\mathrm{C} 2$ during the whole period of reaction.

Comparison of the GC chromatograms and TLC profiles obtained from metabolization of the substrate by the fungus and $\mathrm{C} 1$ led to the following conclusions (Table 2 and Fig. 2):

i- The fungus metabolism towards the exogenous substrate starts before the initial 48 hours of reaction, with formation of a more polar compound (RT 20.37, min, $2.1 \%$ yield);

ii- The substrate concentration decreases until $10^{\text {th }}$ day from which the concentration remains almost constant, indicating no further reactions, in consequence of the metabolization rate decrease. This fact can be a result of the nutrients low levels in the medium, but enzymes inhibition could also have occurred due to the formation of new compounds in the medium.

iii- The yield of the major product increases up to $7.5 \%$, after 6 days of reaction, decreasing to low levels 48 hours later, probably due to a further metabolization of this compound.

iv. After ten days, several other compounds (RT $>22.16$ $\min .7 .7 \%$ yield) can be detected indicating that substrate and products degradation is taking place.

Table 2. Concentration and retention time of the major products detected by Gas Cromatography.

\begin{tabular}{ccc}
\hline $\begin{array}{c}\text { Incubation time } \\
\text { (days) }\end{array}$ & $\begin{array}{c}\mathrm{RT}^{\mathrm{a}} \\
(\mathrm{min})\end{array}$ & $\begin{array}{c}\text { Products formation } \\
(\%)\end{array}$ \\
\hline 2 & 20.37 & 2.1 \\
4 & 20.37 & 3.3 \\
6 & 20.86 & 7.5 \\
8 & 20.91 & 1.2 \\
10 & 23.17 & 1.1 \\
& 23.78 & 1.6 \\
& 30.44 & 1.9 \\
\hline
\end{tabular}

${ }^{\text {a }}$ Retention Time

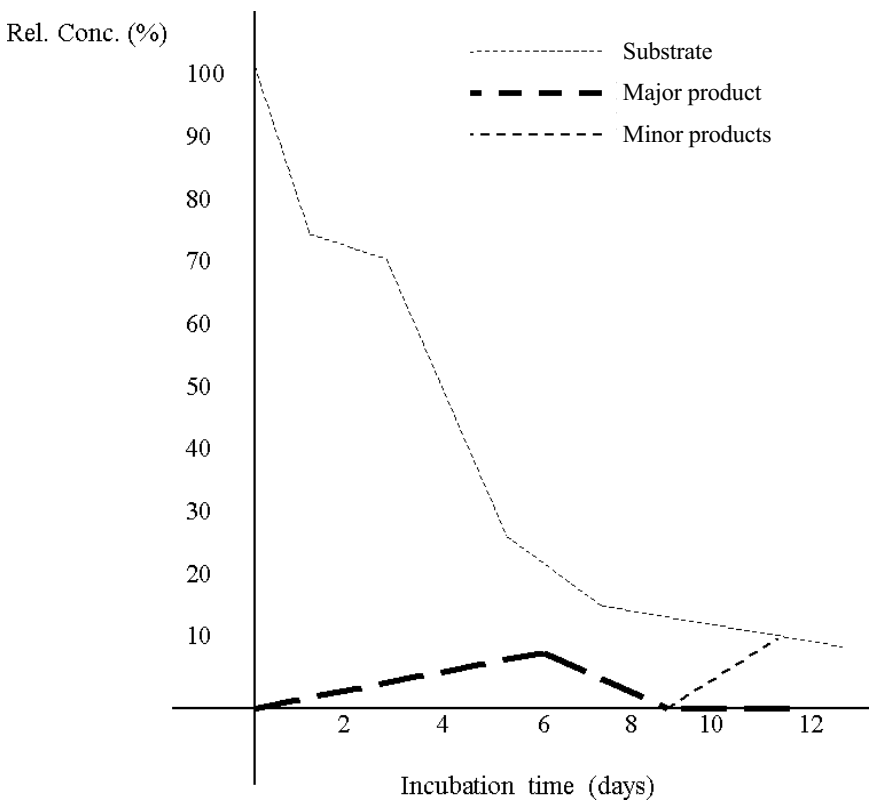

Figure 2. Variation of substrate and products relative concentrations in the biotransformation of methyl trachylobanoate by $C$. aphidicola by GC analysis.

\section{ACKNOWLEDGEMENTS}

The authors thank CNPq and FAPEMIG (Brazil) for grants and financial support and Ms. R. A. de Souza for the GC analysis.

\section{RESUMO}

\section{Otimização do processo de bioconversão de compostos diterpênicos pelo fungo Cephalosporium aphidicola}

Condições otimizadas para a biotransformação de compostos diterpênicos pelo fungo Cephalosporium aphidicola foram determinadas, realizando-se incubações em microescala nas quais variaram-se parâmetros como o tempo de incubação e a quantidade de substrato adicionado. A velocidade (índice) de bioconversão foi monitorada analisando-se os extratos de cultivo através de cromatografia em camada delgada e cromatografia gasosa. Os resultados obtidos mostraram que, para melhores rendimentos, o substrato deve ser adicionado em solução etanólica, na concentração de $15-30 \mathrm{mg}$ por $100 \mathrm{~mL}$ de meio de cultura. A extração de produtos deve ser realizada com acetato de etila, a partir da fase aquosa e do micélio, no sexto dia após a adição do substrato. Estes resultados podem ser utilizados como um roteiro para incubações de compostos estruturalmente semelhantes com o fungo Cephalosporium aphidicola.

Palavras-chave: Cephalosporium aphidicola, biotransformação, diterpenos 


\section{REFERENCES}

1. Boaventura, M.A.D.; Hanson, J.R.; Hitchcock, P.B.; Takahashi, J.A.- The biotransformation of ent-19-hydroxykaur-16-en-15-one by Cephalosporium aphidicola. Phytochemistry, 37: 387-389, 1994.

2. Brooks, D. W. - Enzymes as Catalysts in Organic Synthesis, ed. M.P. Schneider, Dordrecht, D. Reidel Publishing CO, 1986, p.143-169.

3. Godtfredsen, S.E.; Ingvorsen, K.; Yde, B.; Andresen, O. Biocatalysts in Organic Synthesis, Eds. J. Tramper, H.C. van der Plas \& P. Linko, Netherlands, Elsevier, 1985, p. 3-18.
4. Miyazawa, M.; Suzuki, Y.; Kameoka, H.- Biotransformation of (-)-cismyrtanol and (+)-trans-myrtanol by plant pathogenic fungus, Glomerella cingulata. Phytochemistry, 45: 935-943, 1997.

5. Oliveira, A.B.; Hanson, J.R.; Hitchcock, P.B.; Takahashi, J.A.- The biotransformation of ent-15-oxokaur-16-en-10-oic acid and its methyl ester by Cephalosporium aphidicola. Phytochemistry, 40: 439-442, 1995.

6. Queirós, M.; Rebolledo, F.; Liz, R.; Gotor, V.- Enantioselective reduction of $\beta$-keto amides by the fungus Mortiella isabellina. Tetrahedron Asymmetry, 8: 3035-3038, 1997. 